University of Rhode Island

DigitalCommons@URI

Open Access Master's Theses

1973

\title{
Pharmacological Evaluation of an Extract from Eisenia Bicyclis
}

David Michael Whitaker

University of Rhode Island

Follow this and additional works at: https://digitalcommons.uri.edu/theses

\section{Recommended Citation}

Whitaker, David Michael, "Pharmacological Evaluation of an Extract from Eisenia Bicyclis" (1973). Open Access Master's Theses. Paper 229.

https://digitalcommons.uri.edu/theses/229

This Thesis is brought to you for free and open access by DigitalCommons@URI. It has been accepted for inclusion in Open Access Master's Theses by an authorized administrator of DigitalCommons@URI. For more information, please contact digitalcommons-group@uri.edu. 


\title{
PHARMACOLOGICAL EVALUATION OF AN EXTRACT \\ FROM EISENIA BICYCLIS
}

BY

DAVID MICHAEL WHITAKER

\begin{abstract}
A THESIS SUBMITTED IN PARTIAL FULFILLMENT OF THE REQUIREMENTS FOR THE DEGREE OF MASTER OF SCIENCE
\end{abstract}

IN

PHARMACOLOGY AND TOXICOLOGY

UNIVERSITY OF RHODE ISLAND

1973 
EVALUATION OF AN EISENIAN EXTRACT 


\section{MASTER OF SCIENCE THESIS \\ OF}

DAVID MICHAEL WHITAKER

Approved:

Thesis Committee:

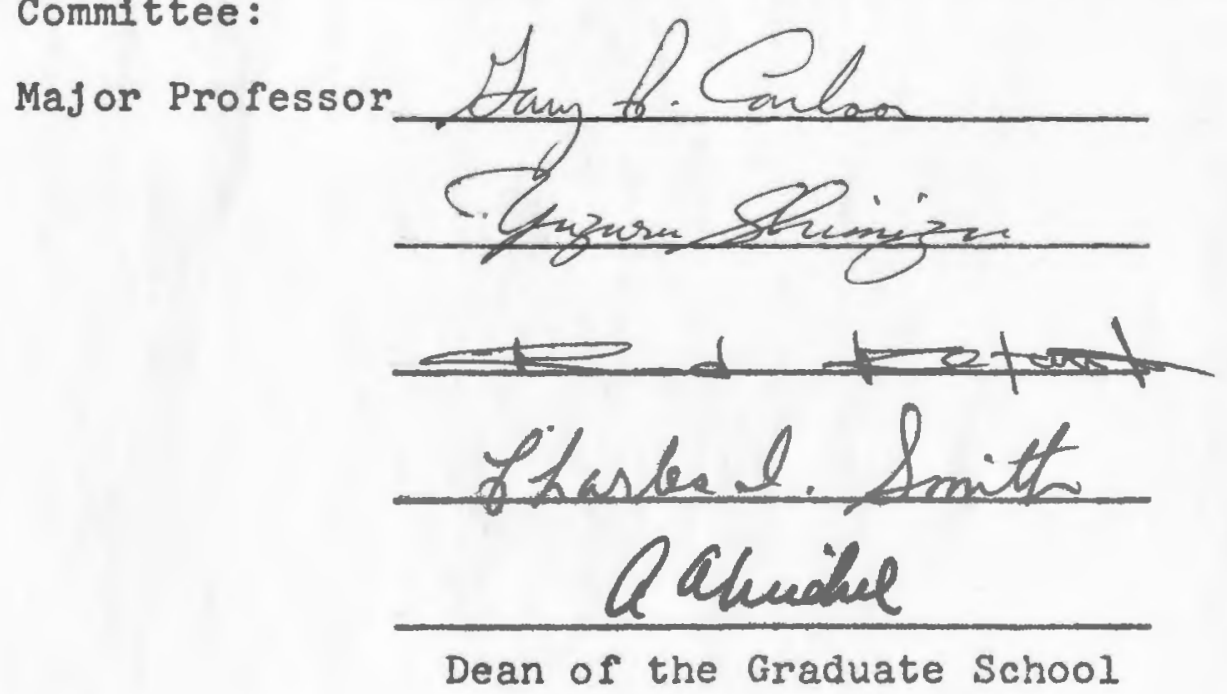

UNIVERSITY OF RHODE ISLAND

1973 


\section{ABSTRACT}

An extract from Elsenia bicyclis containing principally a polyphenolic polymer was examined for pharmacological activity. The investigation centered around the established activity of a model polyphenolic compound, phloroglucinol. Studies on inflammation and alteration of hepatic microsomal enzyme activity were also performed.

Heat denaturation of a $0.15 \%$ bovine serum albumin solution was inhibited $96 \%$ by the addition of the material at a final concentration of $0.32 \mathrm{mg} / \mathrm{ml}$. Since stabilization of such solutions is often indicative of anti-inflammatory activity, direct measurements of this. activity were made. The inhibition of formation of carageenin-induced rat paw edema was utilized as a test system. As determined by paw volume changes, administration of a dose of $75 \mathrm{mg} / \mathrm{kg}$ (1p) one hour prior to carrageenin injection inhibited edema production by 88\%. The potent ant1-inflammatory agent phenylbutazone, at a dose of $90 \mathrm{mg} / \mathrm{kg}$ (1p), provided $100 \%$ protection. The protection given by the Elsenian extract apparently was not due to pitultary-adrenal stimulation, since the protection is 4fold better than that given by a dose of $50 \mathrm{mg} / \mathrm{kg}$ ( $1 \mathrm{p}$ ) of cortisone. The effect cannot be attributed to changes in body temperature, which remains unchanged. The effect can be partially but not completely attributed to the irritant 
properties of the material since buffering a dose of 100 $\mathrm{mg} / \mathrm{kg}$ (1p) provided $42 \%$ protection. The effect is partially due to stabilization of the lysosomal membrane since in vitro 309 ug of the extract per milliliter of incubation media inhibited by $64 \%$ the release of the marker enzyme B-glucuronidase from lysosomes. The compound administered at a dose of $75 \mathrm{mg} / \mathrm{kg}$ (1p) dally for 17 days offered no protection against rat paw edema Induced by Freund's complete adjuvant.

Capillary fraglifty was determined by mouse lung hemoglobin content following sudden decompression. No decrease In fraglilty was observed 1.5 hours after pretreatment with the extract at a dose of $300 \mathrm{mg} / \mathrm{kg}$ (1p).

The materlal administered to $\mathrm{mlce}(300 \mathrm{mg} / \mathrm{kg}$, 1p) 30 minutes prior to administration of lethal doses of curare exhibited protection when the curare was also given by the intraperitoneal route. No protection was exhibited when the curare was adminlstered subcutaneously. This suggested a chemical rather than a pharmacological antagonism. Th1s hypothes1s was supported when no antagonism was found to the action of curare on the cat gastrocnemius muscle in vivo by Jugular infusion of $180 \mathrm{mg}$ of the extract, and when a dose of $300 \mathrm{mg} / \mathrm{kg}$ (1p) one hour prior to sacrifice was found to have no effect on the activity of rat brain cholinesterase. The extract offered no antagonism to the action of either strychnine or tetrodotoxin.

No change in rat liver microsomal enzyme activity, as 
determined by the extent of metabolism of 0 -ethyl 0-(4-nitrophenyl) phenylphosphonothioate (EPN) was found after the administration of $300 \mathrm{mg} / \mathrm{kg}$ (1p) of the material dally for 3 days. Also, a single infection of $300 \mathrm{mg} / \mathrm{kg}$ (1p) 1 hour prior to sacrifice for measurement of activity was without effect.

Estrogenic activity was assayed by changes in uterine weight in the immature female rat. The administration of $300 \mathrm{mg} / \mathrm{kg}$ of the extract intraperitoneally dally for 3 days did not alter uterine welght.

Rat liver homogenates were assayed for tryptophan pyrrolase activity by measuring the formation of the endproduct kynurenine. The administration of $300 \mathrm{mg} / \mathrm{kg}$ (1p) of the extract 1.5 hours prior to sacrifice caused $33 \%$ inhib1tion of the enzyme activity. The presence of the extract at a concentration of $486 \mathrm{\mu g} / \mathrm{ml}$ resulted in an in vitro inhibition of $82 \%$. 


\section{ACKNOWLEDGEMENTS}

The author wishes to express his gratitude to his wife Rosemary for her support and understanding.

Dr. Gary P. Carlson provided Invaluable guidance throughout this study. Mr. Steven Zelenski and Dr. Leonard Worthen were kind enough to supply the Elsenian extract.

Th1s work was supported by the Sea Grant College Program at the University of Rhode Island. 
TABLE OF CONTENTS

ABSTRACT..............................

ACKNOWLEDGEMENTS $\ldots \ldots \ldots \ldots \ldots \ldots \ldots \ldots \ldots \ldots \ldots \ldots \ldots \ldots \ldots \ldots \ldots$ iv

TABLE OF CONTENTS........................... I

LIST OF TABLES.................................... 3

LIST OF FIGURES......................... 5

I. INTRODUCTION....................... 6

II. REVIEW OF THE LITERATURE.............. 8

III. EXPERIMENTAL...................... 12

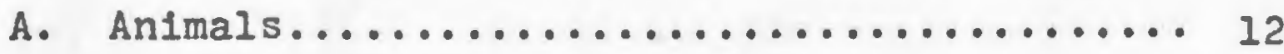

B. Materials....................... 12

c. Analytical Procedures................... 13

1. Turb1dimetric Determination of Heat

Denaturation of Bovine Serum Albumin... 13

2. Plethysmographic Rat Paw Volume

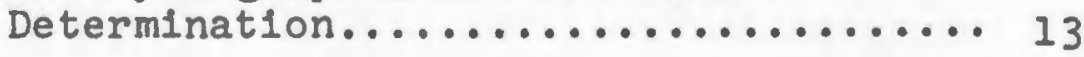

3. Carrageenin-Induced Rat Paw Edema..... 14

4. Determination of Thermogenic Activity.. 14

5. Harvesting of Lysosomes and Determination of the Activities of $\beta$ glucuronidase and Acld Phosphatase.... 15

6. Freund's Adjuvant-Induced Rat Paw Edema....................... 17

7. Induction of Mouse Lung Hemorrhage and Lung Hemoglobin Determination........ 17

8. In vivo Antagonism of Curare, Strychnine, or Tetrodotoxin in Mice.... 18 
9. Determination of Acetylcholinesterase Act1vity....................... 18

10. Cat Sc1at1c Nerve-Gastrocnemius Muscle Preparation................ 19

11. Determination of EPN Detoxification....2 20

12. Determination of L-Tryptophan Pyrrolase Act1vity.................. 21

13. Determination of Estrogenic Act1vity.... 22

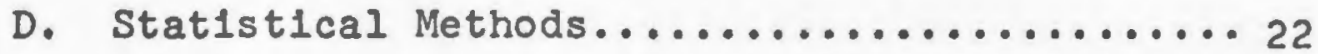

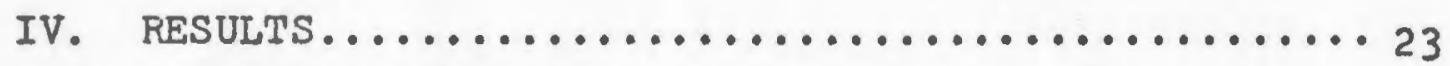

v. DISCUSSION............................ 46

VI. SUMMARY AND CONCLUSIONS ................ 55

viI. REFERENCES........................ 58 
LIST OF TABLES

Table

Page

1. Effect of c4OSA on heat denaturation of bovine

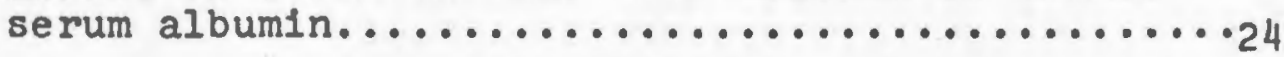

2. Effect of phloroglucinol on heat denaturation of bovine serum albumin...................25

3. Effect of drugs on carrageenin-induced rat paw edema............................26

4. Effect of neutralized or buffered ec40SA on carrageenin-induced rat paw edema.............29

5. Effect of drugs on lysosomal membrane stability

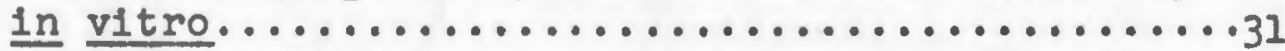

6. Effect of f4OSA and refined 40SA on lysosomal

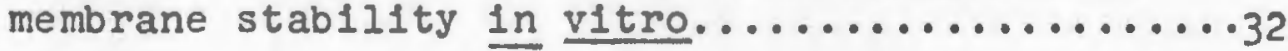

7. Antagonism of Freund's adjuvant-induced rat

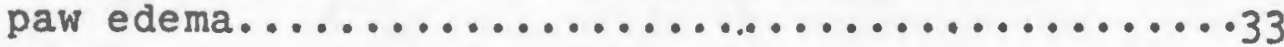

8. Effect of drugs on mouse lung hemorrhage induced by sudden decompression........................

9. Protection against curare poisoning in mice by

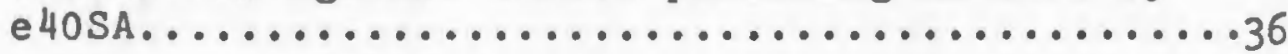

10. Protection against curare poisoning in mice by

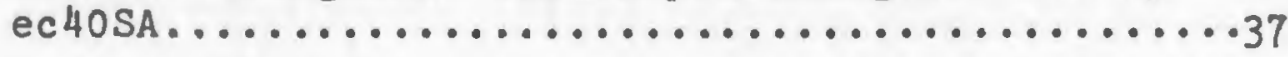

11. Effect of ec40SA in vivo and in vitro on rat brain cholinesterase activity..............38

12. Effect of ec40SA on strychnine poisoning in mice.................................40

13. Effect of P4OSA on tetrodotoxin poisoning in mice...............................

14. Effect of drugs on EPN detoxification.........42

15. Effect of drugs in vivo and in vitro on rat liver tryptophan pyrrolase activity..........43 
Table

Page

16. Effect of drugs on rat uterine weight.........45 


\section{LIST OF FIGURES}

Figure

Page

1. Effect of e4OSA on rat body temperature.......28 


\section{INTRODUCTION}

Many naturally derived compounds are used extensively in medicine. Some outstanding examples are digitalis, reserpine, atropine, and colchicine. Desplte the awareness of the origins of such drugs from terrestrial plants, unt1l recently there has been relatively little effort made to examine marine species for pharmacological agents. Extensive research is needed in this area, considering that of the 500,000 species which inhab1t the water, less than one percent have been examined for blological activity.

The drugs which have been 1solated from marine plants exhibit a wide varlety of pharmacological activity. The following are some representat1ve examples (Der Marderosian, 1969). The fungus Cephalosportum acremonium is the source of cephalothin, an antiblotic which is active against various penic1llin-resistant microbes. The algae Lyngbya majuscula has been 1mplicated in outbreaks of dermatitis among swimmers, and toxicity in fish and mice. However, extracts of this algae have also shown antimicrobial, antiviral, funglcidal, and other types of growth-inhibitory properties in prelimInary pharmacological studies. The algae Digenea simplex has ylelded the anthelmintic kalnic acld. Chondrus crispus is the source of the linear polysaccharlde carrageenin, 
which exhib1ts antipeptic, anticoagulant, and ant1thrombic properties. More thorough screening programs would undoubtedly uncover more agents from fust these four species.

In this study, an extract from the algae E1senia b1cyclis (Kjellman) Setchell, native to the shores of Korea, contalning principally a polyphenolic polymer, has been examined for pharmacological activity. The investigation centered around the established activity of a model polyphenolic compound, phloroglucinol, or 1,3,5-trihydroxybenzene. Studies on inflammation and alteration of hepatic microsomal enzyme activity were also performed. 


\section{REVIEW OF THE LITERATURE}

The pharmacological activity of phloroglucinol (1,3,5trihydroxybenzene) has been Investigated by several groups. Okanishi and Shimaoka (1952) determined by gross observation that phloroglucinol pretreatment could decrease mouse lung caplllary fragility, ut1lizing a decompression hemorrhaging technique developed by Majovsk1 et al. (1944). To Induce lung hemorrhage, mice were placed in a chamber which was decompressed to $40 \mathrm{~mm} \mathrm{Hg}$. The animals were removed from the chamber after two minutes and the lungs were exclsed and Judged for extent of hemorrhage according to an arbitrary rating system. A capillary stabilizing effect uncovered by this fragility screen might find application in hypobaric environments or in the treatment of hypertension.

Frieden et al. (1961) reported that phloroglucinol non-competitively blocks the conversion of L-tryptophan to kynurenine by the liver enzyme tryptophan pyrrolase. Elghtyone percent inhibition was achleved at a concentration of $3.0 \mathrm{mM}$. Such an inhibition in vivo could result in nicotinic acid deficlency.

Mogey and Young (1949) investigated the in vitro effect of phloroglucinol on the curarized rat diaphragm. In this experiment, the $A D 66 / 33$ of phenol, 1.e., that amount of phenol which reduces by half the activity of an amount of 
d-tubocurarine which by 1 tself would have effected 66.7 percent paralysis, was established as a bas1s for the comparison of the antagonism offered by other phenols. The AD66/33 for phenol was found to be $1.52 \mathrm{mg}$. The relative activity, on a weight for weight basis, for phloroglucinol was found to be one-tenth that of phenol. Thus the authors concluded that phloroglucinol acted as a very weak curare antagonist. No inhibition of rat brain acetylcholinesterase or pseudo (horse serum) cholinesterase was exhibited, nor was the $\mathrm{pH}$ of the medium affected enough to alter the action of the curare. Thus the mechanism of the antagonism was unexplained. It has been demonstrated that a varlety of phenollc substances such as genistein and coumestrol possess estrogenlc act1vity (B1ggers and Curnow, 1954; B1ckoff et al., 1958). The administration of such agents could result in infertil1ty due to suppressed hypophyseal gonadotropin resulting in a disturbed estrous cycle.

Conney (1967) discussed extensively the pharmacological 1mplications of the alteration of the activity of the drugmetabolizing liver microsomal enzyme system. Specifically, the administration of certain drugs, such as phenobarbital and 3-methylcholanthrene, results in enhanced metabolism of other agents due to induction of the enzyme system. Because of this important source of drug interaction, it appears important to test all drugs and chemical agents for the ability to induce or inhibit drug metabolizing activity. According to Neal and DuBo1s (1965), metabolism of the 
pesticlde 0-ethyl 0-(4-n1tropheny1) phenylphosphonothioate (EPN) by rat liver microsomal enzymes provides an indication of the activity of that system, thus providing a method to investigate the effect of drugs on this metabolic pathway. Measurement of the anti-inflammatory activity of drugs is a complex problem and many methods and models have been proposed and utilized. Grant et al. (1970) demonstrated that anti-inflammatory drugs such as aspirin and indomethacin are often capable of inhlbiting the heat denaturation of bovine serum albumin solutions. Winter et al. (1962) concluded that the polysaccharlde carrageenin was highly sulted as a phlogistin in the rat paw edema model of Inflammation. Pearson (1956) showed that Freund's complete adjuvant, a suspension of heat-killed Mycobacterium butyricum in paraffin, when infected into the paw of the rat, could elic1t a polyarthritis syndrome which could serve to further evaluate ant1-inflammatory agents. Van Arman et al. (1965) described a highly sensitive mercury displacement plethysmograph which could be employed to quantitate rat paw volumes in confunction with paw edema models of inflammation. The device is essentially a mercury-filled syringe connected to a blood pressure transducer which is in turn wired to a polygraph amplifier. The introduction of objects into the mercury results in a linear response on the amplifier recorder.

Many mechanisms have been proposed for the action of anti-inflammatory agents. Labilization of the lysosomal 
membrane and subsequent tissue dissolution due to the release of degradative lysosomal enzymes has been implicated as a mechanism underlying several types of inflammation, ranging from heat and chemical burns to arthritis (Houck and Forscher, 1968). Ignarro (1971), ut1lizing the release of

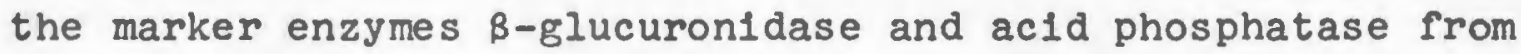
the lysosome, has demonstrated that ant1-inflammatory drugs are often capable of stabilizing the membrane of that organelle. Such stabilization may therefore partially explain the mechanism of action of many anti-inflammatory agents.

Garattini et al. (1965) indicate that many chemical agents, such as hypertonic saline, acetic acld, and formaldehyde, when infected by a general route, possess antiinflammatory activity by virtue of their irritant properties, which allow for a minimization of local edema formation. The screening of new anti-inflammatory agents must therefore account. for possible irritant effects. 


\section{EXPERIMENTAL}

\section{A. Animals}

Sprague-Dawley derlved random bred albino rats were obtained from Charles River Breeding Laboratories, Wilmington, Massachusetts. Male rats employed weighed 200-250 $\mathrm{g}$ while female rats welghing 55-65 $\mathrm{g}$ were used. Male mice, 35-42 $\mathrm{g}$, were obtained from the same breeder. The animals were housed in quarters maintained at $21-23^{\circ} \mathrm{C}$ with room lights on alternating 12 hour I1ght-dark cycles. Commerclal laboratory chow and water were allowed ad libitum. Animals were used no earlier than 3 days following recelpt from the supplier.

\section{B. Materials}

Analytical grade chemicals or equivalent were used throughout the study. Cofactors (NADP and glucose-6phosphate) and substrates (L-tryptophan, p-nitrophenyl phosphate, phenolphthalein glucuronide, and acetylcholine chloride) were obtalned from Calbiochem or Sigma Chemicals. Phenylbutazone and EPN were gifts of Ge1gy Pharmaceuticals and DuPont respectively. Drugs were obtalned from their respective manufacturers. Water employed as a solvent was double-dist1lled.

The molecular welght of the Elsenian extract has been 
determined to be about 10,000 . The extract w1ll be referred to as $4 O S A$, preceded by letters which indicate the extraction batch.

Recent evidence suggests that an integral part of the polyphenolic polymer is polysaccharlde (Zelensk1, 1973). C. Analytical Procedures

All incubations except for determination of chollnesterase activity were carried out in a Dubnoff metabolic shaker under an atmosphere of a1r. All absorbance determinations were made utilizing a Beckman DB-G spectrophotometer. Unless otherwise Indicated, all 40SA fractions were dissolved in water or saline. 1. Turbidimetric Determination of Heat Denaturation of Bovine Serum Albumin

The extent of heat-induced denaturation of bovine serum albumin (BSA) was quantitated by a method suggested by Grant et al. (1970). Equal amounts of 0.3\% BSA and buffer or drug solution were heated at $70^{\circ} \mathrm{C}$ for 4 minutes, cooled in 1 ce water for 3 minutes, maintained at room temperature for 15 minutes, and the resultant degree of turbidity was determined by the absorbance at $660 \mathrm{~nm}$. The buffer employed was $0.05 \mathrm{M}$ Tris acetate, $\mathrm{pH} 6.0$, and was employed as the solvent for c40SA. Phloroglucinol was dissolved in buffer contalning $2.5 \%$ dimethylformamide. 2. Plethysmographic Rat Paw Volume Determination

Rat paw volume was determined by a plethysmographic technique described by Van Arman et al. (1965). 
A $30 \mathrm{cc}$ capacity syringe was filled with mercury and connected by means of cannula tubing to a Statham blood pressure transducer which in turn was wired to a Grass polygraph amplifier. The introduction of objects into the mercury resulted in a linear recorder output response from the amplifier. The apparatus was calibrated by the introduction of objects of known volume. Rat paws were prepared for volume measurement by marking just above the topmost callus pad. Paws were 1mmersed to this mark in the mercury during measurement.

\section{Carrageenin-Induced Rat Paw Edema}

Carrageenin was utilized as a phlogistin to induce rat paw edema as suggested by Winter et al. (1962).

Male rats were administered (1p) either saline, 90 $\mathrm{mg} / \mathrm{kg}$ phenylbutazone, $50 \mathrm{mg} / \mathrm{kg}$ cortisone, or $75 \mathrm{mg} / \mathrm{kg}$ c40SA. One hour later, $0.1 \mathrm{ml}$ of $1.0 \%$ carrageenin in saline was injected into the sub-plantar tissue of the hind paw, using a 26 gauge needle. The paw volume was determined immediately plethysmographically, and again three hours later, and edema formation was calculated in $\mathrm{mm}^{3}$.

4. Determination of Thermogenic Activity

Thermogenic activity was determined by monitoring the rectal temperature of rats using a Yellow Springs Instrument Co. thermistor thermometer, model 8420. Saline or $75 \mathrm{mg} / \mathrm{kg}$ or $150 \mathrm{mg} / \mathrm{kg}$ e40SA was administered (1p) to male rats and rectal temperature was determined $(2.5 \mathrm{~cm}$ probe 
Insertion) immediately and every hour thereafter for four hours. Animals were housed three per cage; amblent temperature was $24^{\circ} \mathrm{C}$.

5. Harvesting of Lysosomes and Determination of the Activities of B-Glucuronidase and Ac1d Phosphatase

Lysosomal fractions were prepared according to the method suggested by Ignarro (1971). The determination of the activities of the lysosomal enzymes B-glucuronidase and ac1d phosphatase was also performed by the method reported by that author.

The liver from a decapltated and exsanguinated male rat was exc1sed and a $10 \%$ homogenate prepared in cold $0.25 \mathrm{M}$ sucrose-0.02 M Tris acetate buffer, $\mathrm{pH} 7.4$. The homogenate $(40 \mathrm{ml})$ was then centrifuged at $600 \mathrm{~g}$ for $5 \mathrm{mln}$ at $4^{\circ} \mathrm{C}$ in a Sorvall RC2-B centrifuge (\# 34 rotor). The resulting supernatant was decanted ard diluted with an equal volume of the same buffer, and centrifuged at $3500 \mathrm{~g}$ for $15 \mathrm{~min}$ at $4^{\circ} \mathrm{C}$. The intact pellet was rinsed gently twice In $0.45 \mathrm{M}$ sucrose-0.04\% glycogen-0.02 M Tris acetate buffer, $\mathrm{pH} 7.4$, and resuspended in $4.0 \mathrm{ml}$ of the same buffer. The suspensions were maintained at $4^{\circ} \mathrm{C}$.

Labilization or stabilization of lysosomes was ascertained by determining the release of lysosomal marker enzymes. The lysosomal suspension was warmed to $25^{\circ} \mathrm{C}$ for $5 \mathrm{~min}$ and $0.2 \mathrm{ml}$ allquots were added to $20 \mathrm{ml}$ glass beakers containing $2.0 \mathrm{ml}$ of $0.18 \mathrm{M}$ sucrose-0.04 M Tris acetate buffer, $\mathrm{pH} 7.4$, with elther $0.1 \mathrm{ml}$ drug solution or water, 
and the beakers were incubated at $37^{\circ} \mathrm{C}$ for 0 or $15 \mathrm{~min} \mathrm{in}$ a Dubnoff metabolic shaker. The incubation was terminated by high speed centrifugation $\left(27,000 \mathrm{~g}\right.$ for $15 \mathrm{~min}$ at $\left.4^{\circ} \mathrm{C}\right)$ after transfer of the samples to polyethylene tubes. When appropriate the direct effect of the drugs on the marker enzymes was determined. In this case the drugs were added to the system after the incubation period. To determine the total enzyme activity of the system, $2.0 \mathrm{ml}$ of $0.2 \%$ (v/v) Triton X-100 in $0.04 \mathrm{M}$ Tris acetate buffer, $\mathrm{pH} 7.4$, replaced the $2.0 \mathrm{ml}$ of buffer in the incubation.

Ac1d phosphatase and $\beta-g l$ lucuronidase were employed as lysosomal marker enzymes. The formation of p-nitrophenol from p-nitrophenyl phosphate was measured to determine ac1d phosphatase activity. The formation of phenolphthalein from phenolphthalein glucuronide was estimated to assay B-glucuronidase activity. One milliliter of high speed supernatant and $1.0 \mathrm{ml}$ of distilled water were added to $1.0 \mathrm{ml}$ of $0.3 \mathrm{M}$ citrate buffer, $\mathrm{pH} 4.8$. Incubation (at $37^{\circ} \mathrm{C}$ for $20 \mathrm{~min}$ ) was initiated by the addition of $0.04 \mathrm{ml}$ of freshly prepared substrate (e1ther p-nitrophenyl phosphate, $79 \mathrm{mg} / \mathrm{ml}$ in distllled water, or phenolphthalein glucuronide, $63 \mathrm{mg} / \mathrm{ml}$ in distilled water). Blanks recelved water in place of substrate. Acld phosphatase determinations were terminated by the addition of $0.2 \mathrm{ml}$ of $4 \mathrm{~N} \mathrm{NaOH}$, and absorbances were then determined at $405 \mathrm{~nm}$. B-glucuronidase assays were terminated by the addition of $0.4 \mathrm{ml}$ of $2.2 \mathrm{M}$ 
glycine- $\mathrm{NaOH}$ buffer, $\mathrm{pH} 12$, and absorbances were then measured at $540 \mathrm{~nm}$. The absorbances obtalned were compared with those of standard solutions of phenolphthalein and p-nitrophenol.

6. Freund's Adjuvant-Induced Rat Paw Edema

Polyarthritis was induced in rats by treatment with complete Freund's adjuvant according to the method of Pollock and Brown (1971).

Male rats were treated dally for 17 days with elther saline (1p), $75 \mathrm{mg} / \mathrm{kg}$ f4OSA adfusted to $\mathrm{pH} 7.0$ with $\mathrm{NaOH}$ (1p), or $2 \mathrm{mg} / \mathrm{kg}$ triamcinolone (sc). On the second treatment day, $0.1 \mathrm{ml}$ Freund's complete adjuvant, contalning 10 mg heat-killed Mycobacterium butyricum per milliliter of 15\% mannide monooleate in paraffin o1l, was infected into the sub-plantar tissue of the hind paw, using a 26 gauge needle. The paw volume was determined 1mmediately plethysmograph1cally and again on day 18, and edema formation calculated.

7. Induction of Mouse Lung Hemorrhage and Lung Hemoglobin Determination

Lung hemorrhage was Induced by sudden decompression, a method developed by Majovsk1 et al. (1944). A 30 liter vacuum sink was evacuated to $40 \mathrm{~mm} \mathrm{Hg}$. Mice in a 1.5 liter test chamber at atmospherlc pressure were subjected to the lower pressure by the opening of a stopcock. Within 20 seconds the pressure in the two chambers equilibrated at $70 \mathrm{~mm} \mathrm{Hg}$. The mice died w1thin 60-90 seconds and were removed from the chamber after two minutes. The lungs were 
rapidly excised, welghed, homogenized in 25 volumes of cyanomethemoglobin reagent and centrifuged to sediment t1ssue. The supernatant was examined for hemoglobin content by determining absorbance at $540 \mathrm{~nm}$. The remaining homogenate was dried to constant welght at $85^{\circ} \mathrm{C}$. Results were reported as $\mathrm{mg}$ hemoglobin per $\mathrm{mg}$ dry lung. The resulting values were compared to those of control animals maintained at atmospheric pressure. Animals were administered (1p) saline, $300 \mathrm{mg} / \mathrm{kg}$ e40SA, $300 \mathrm{mg} / \mathrm{kg}$ phloroglucinol, or $100 \mathrm{mg} / \mathrm{kg}$ phenylbutazone 1.5 hours prior to sacrifice. 8. In vivo Antagonism of Curare, Strychnine, or Tetrodotoxin In Mice

Lethal doses of curare, strychnine, or tetrodotoxin were administered to mice to investigate antagonism to these agents. The E1senian extract at a dose of $300 \mathrm{mg} / \mathrm{kg}$ or saline was administered intraperitoneally to mice 30 minutes prior to the administration ( $1 p$ or $s c$ ) of elther curare $(0.28-0.60 \mathrm{mg} / \mathrm{kg})$, strychnine $(2.0 \mathrm{mg} / \mathrm{kg})$, or tetrodotoxin $(12 \mu \mathrm{g} / \mathrm{kg})$. These doses are close to the respective $L_{50}$ 's. The number of animals infected and the number of survivors were recorded.

9. Determination of Acetylcholinesterase Activity

The activity of rat brain acetylcholinesterase was estimated by the manometric method suggested by DuBo1s and Mangun (1947) employing the Warburg apparatus.

Male rats were administered (1p) either saline or 300 $\mathrm{mg} / \mathrm{kg}$ ec40SA one hour prior to sacrifice for brain excision. 
Ten percent brain homogenates were prepared in calclumfree Ringer-bicarbonate buffer. One-half milliliter of homogenate and $2.2 \mathrm{ml}$ buffer were transferred to the main compartment of the Warburg rlask. In vitro experlments included the addition of ec4OSA at a concentration of $5 \mathrm{mg} / \mathrm{ml}$ to the maln compartment. The flasks were flushed for 5 minutes with 95:5 $\mathrm{N}_{2}: \mathrm{CO}_{2}$ whlle they equilibrated to the temperature of the water bath $\left(38^{\circ} \mathrm{C}\right)$. The reaction was initiated by tipping into the main compartment the contents of the side-arm $(0.3 \mathrm{ml}$ of $0.1 \mathrm{M}$ acetylcholine chloride). After another 5 minute equilibration, the manometer readlings of the amount of $\mathrm{CO}_{2}$ produced by the enzymatic hydrolysis of the acetylcholine were recorded at 5 minute intervals for 30 minutes. The $\mathrm{CO}_{2}$ production was corrected for both tissue and acetylcholine blanks and for thermobarometer changes.

10. Cat Sclatic Nerve-Gastrocnemius Muscle Preparation The in vivo cat sciatic nerve-gastrocnemius muscle preparation was utilized to quantitate curare antagonism.

A $3.2 \mathrm{~kg}$ cat was anesthet1zed with $1.5 \mathrm{~g} / \mathrm{kg}$ urethane (1p). The left jugular vein was cannulated and used for infusion of drugs. The right carotid artery was cannulated and connected to a Statham blood pressure transducer wh1ch was in turn wired to a Grass polygraph amplifler to monitor blood pressure. Forty units/kg of heparin were infused to prevent clotting. An automatic respirator was connected to a tracheal cannula. The left gastrocnemlus muscle was 
connected to a Grass force transducer which was in turn wired to a Grass polygraph amplifier to record muscle activity. The left sclatic nerve recelved a $1.0 \mathrm{~V}$ stimulus lasting $0.1 \mathrm{msec}$ at a rate of $12 / \mathrm{minute.} \mathrm{This}$ stimulus effected an initial contractile force of 980 dynes. d-Tubocurarine chloride was infused unt1l a $70 \%$ reduction in contractile force was obtained. The followIng drugs were infused, in order, over perlods of 3,6 , or 9 minutes respectively: $0.18 \mathrm{mg}$ physostigmine, $30 \mathrm{mg}$ phloroglucinol, or $180 \mathrm{mg}$ e40SA. Additional curare was infused between drugs as needed to reinstate the reference curarization level.

11. Determination of 0-Ethyl 0-(4-nitropheny 1) phenylphosphonothioate Detoxification.

The detoxification of 0-ethyl 0-(4-nitropheny 1$)$ phenylphosphonothioate (EPN) was estimated by measuring the formation of the resultant p-nitrophenol according to the method of Neal and DuBols (1965).

To an incubation mixture containing 1.3 umoles NADP, 3.3 umoles glucose-6-phosphate, $0.2 \mathrm{ml}$ EPN-buffer and sufficient water to make a total volume of $0.8 \mathrm{ml}$ was added $0.1 \mathrm{ml} 20 \%$ rat liver homogenate in $1.15 \% \mathrm{KCl}$ contalning $0.25 \%$ nicotinamide. The EPN-buffer was prepared by dissolving $7.0 \mathrm{mg}$ EPN in $1.0 \mathrm{ml} \mathrm{1:4}$ ethanol: propylene glycol and adding $0.5 \mathrm{ml}$ of this solution to $5.0 \mathrm{ml}$ of $0.1 \mathrm{M}$ phosphate buffer, pH 7.8.

Incubation was carried out at $37^{\circ} \mathrm{C}$ for $60 \mathrm{~min}$. The 
reaction was terminated by adding $2.5 \mathrm{ml}$ cold acetone to the reaction flask. The flask contents were transferred to centrifuge tubes containing $0.2 \mathrm{ml}$ glycine-NaOH buffer $(0.5 \mathrm{M}, \mathrm{pH} 9.5)$. The tubes were centrifuged and the absorbance of the supernatant was determined at $410 \mathrm{~nm}$ versus a blank to which tissue had been added at the termination of the incubation. The amount of p-nitrophenol formed was determined by comparison with the absorbance of known quantities of the chemical.

12. Determination of L-Tryptophan Pyrrolase Activity L-tryptophan pyrrolase activity of rat liver homogenates was estimated through assay of the end product kynurenine, according to the method of Knox and Mehler (1950).

Incubations were carried out at $37^{\circ} \mathrm{C}$ for 60 minutes in media containing 7.5 mmoles L-tryptophan, $2.0 \mathrm{ml}$ of $0.1 \mathrm{M}$ phosphate buffer, $\mathrm{pH} 7.0$, and $0.8 \mathrm{ml} 25 \%$ l1ver homogenate in $0.15 \mathrm{M} \mathrm{KCl}$ in a total volume of $4.0 \mathrm{ml}$. For in vitro investigation, $1.94 \mathrm{mg}$ of phloroglucinol or f4OSA was added. To examine the in vivo effects of drugs on the enzyme, animals were infected (1p) 1.5 hours prior to sacrifice with saline, $300 \mathrm{mg} / \mathrm{kg}$ phloroglucinol, or $300 \mathrm{mg} / \mathrm{kg}$ e $40 \mathrm{SA}$; or with $35 \mathrm{mg} / \mathrm{kg}$ hydrocortisone four hours prior to sacrifice for liver excision.

The reaction was terminated by the addition of 2.0 ml of $15 \%$ metaphosphoric acid. The flask contents were filtered and a $3.0 \mathrm{ml}$ aliquot of the filtrate was 
neutralized with $1.0 \mathrm{mI}$ of $1 \mathrm{~N} \mathrm{NaOH}$. The absorbance was then determined at $365 \mathrm{~nm}$ versus a blank to which the homogenate had been added after the metaphosphoric acid. The amount of kynurenine formed was calculated from the absorbance of solutions of kynurenine of known concentration.

\section{Determination of Estrogenic Activity}

To determine estrogenic activity, immature female rats were injected daily for three days with either saline (1p), $303^{\circ} \mathrm{mg} / \mathrm{kg}$ f $40 \mathrm{SA}$ (1p), or $25 \mu \mathrm{g} / \mathrm{animal}$ estradiol-17-B(sc). The estradiol was prepared by diluting $1.0 \mathrm{ml}$ of a $25 \mathrm{mg} / 100 \mathrm{ml} 95 \%$ ethanol stock solution with $4.0 \mathrm{ml}$ saline. On the fourth day, the uterus was excised, welghed, and the uterine-to-body welght ratio calculated.

D. Stat1stjcal Methods

The 2-talled student's " $t$ " test for 1ndependent means was used to examine experimental means for statistical significance. The level of signiflcance (P) was determined by comparison of the computed"t" value with values from standard tables. All calculated " $t$ " values were tested at both the 0.05 and 0.01 probab1lity levels for rejection of the null hypothesis. 


\section{RESULTS}

\section{Inflammation}

The extract was inftially evaluated by means of the albumin denaturation test, which is used to screen new drugs for anti-inflammatory activity. The results of this screening procedure are shown in Tables 1 and 2. Table 1 shoms that the heat denaturation of a $0.15 \%$ bovine serum albumin solution was inhibited $96 \%$ by the addition of the extract at a final concentration of $0.32 \mathrm{mg} / \mathrm{ml}$, and that there was a dose dependent relationship at lower concentrations. Table 2 shows that the model compound, phloroglucinol, enhanced by at least $24 \%$ the denaturation process.

Since the extract exhibited activity in the in vitro anti-inflammatory test system, determination of its effect In an intact animal model of inflammation would be valuable. Table 3 summarizes the results of an anti-inflammatory study employing as a model carrageenin-induced rat paw edema. The extract, admintstered at a dose of $75 \mathrm{mg} / \mathrm{kg}$ (ip) one hour prior to carrageenin injection, inhibited edema formation by $88 \%$. The administration of the potent ant $1-$ Inflammatory agent phenylbutazone $(90 \mathrm{mg} / \mathrm{kg}$ ) inhibited edema production by $100 \%$ and also allowed for a partial absorption of the infected carrageenin. Administration of 
Table 1. Effect of C4OSA on heat denaturation of bovine serum albumin.

\begin{tabular}{c}
$\begin{array}{c}\text { C4OSA } \\
\text { CONCENRATION } \\
\mathrm{mg} / \mathrm{ml}\end{array}$ \\
\hline 0.0 \\
0.005 \\
0.01 \\
0.02 \\
0.04 \\
0.08 \\
0.16 \\
0.32 \\
0.64
\end{tabular}

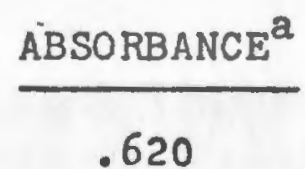

7 CONTROL

100

89

.550

90

.560

55

.340

56

.345

8

.049

6

.036

4

.022

15

$a_{\text {Determined at }} 660 \mathrm{~nm}$. 
Table 2. Effect of phloroglucinol on heat denaturation of bovine serum albumin.

$\begin{array}{lcc}\begin{array}{c}\text { PHLOROGLUCINOL } \\ \begin{array}{c}\text { CONCENTRATION } \\ \mathrm{mg} / \mathrm{ml}\end{array}\end{array} & \text { ABSORBANCE } & \text { \% CONTROL } \\ 0.0 & 0.76 & 100 \\ 0.50 & 1.00 & 132 \\ 0.25 & 1.00 & 132 \\ 0.125 & 1.00 & 132 \\ 0.062 & 1.00 & 132 \\ 0.031 & 1.00 & 132 \\ 0.015 & 1.10 & 145 \\ 0.0075 & 0.95 & 125 \\ 0.0037 & 0.96 & 126 \\ 0.0018 & 0.94 & 124 \\ 0.0009 & 1.10 & 145\end{array}$

${ }^{2}$ Determined at $660 \mathrm{~nm}$. 
Table 3. Effect of drugs on carrageenin-induced rat paw edema.

TREATMENT $^{\mathrm{a}}$

Saline

C4OSA

(75 $\mathrm{mg} / \mathrm{kg}$, 1p)

Phenylbutazone

(90 $\mathrm{mg} / \mathrm{kg}$, Ip)

Cortisone

(50 $\mathrm{mg} / \mathrm{kg}$, 1p)
MEAN EDEMA $\pm S E, \mathrm{~mm}^{3}(4)^{\mathrm{b}} \quad \%$ CONTROL

$1363 \pm 206 \quad 100$

$163 \pm 69^{c} \quad 12$

$-100 \pm 71^{c} \quad-7$

$738 \pm 97^{d}$

54

${ }^{2}$ Drugs were administered 1 hour prior to carrageenin injection.

${ }^{b}$ Number of animals.

$c_{\mathrm{P}}<.01$

$\mathrm{d}_{\mathrm{P}<.05}$ 
the sterold cortisone $(50 \mathrm{mg} / \mathrm{kg}$ ) inhibited edema formation by $46 \%$. The effects of the above drugs were significant at the $P<.05$ level.

Several experiments were undertaken to determine the mechanism of action of the extract as an anti-inflammatory agent in the carrageenin paw edema system. The first of these, a study of the effect of the extract on rat body temperature, is summarized in Figure 1. The extract, at a dose of elther 75 or $150 \mathrm{mg} / \mathrm{kg}$, had a negliglble effect on body temperature over a period of four hours.

Since some compounds have been shown to possess ant1inflammatory activity due to irritant properties, an experiment was conducted to determine whether the extract was an irritant by virtue of its acidity. The carrageenin paw edema model was again employed, and the extract, at a dose of $100 \mathrm{mg} / \mathrm{kg}$, was e1ther buffered at or neutralized to pH 7.4. Table 4 shows the results of this study. The neutralized extract did not offer statistically significant protection ( $76 \%$ of control) while the buffered material Inhibited edema formation by $42 \%(P<.05)$.

Stabilization of the lysosomal membrane has also been invoked as a mechanism of action of various anti-inflammatory agents. The degree of stabilization or labilization can be inferred from the extent of release of the lysosomal marker enzymes acid phosphatase and $\beta$-glucuronidase. The extract was so examined for 1ts effect on the lysosomal membrane. The results of this study are shown in Tables 5 and 6 . 


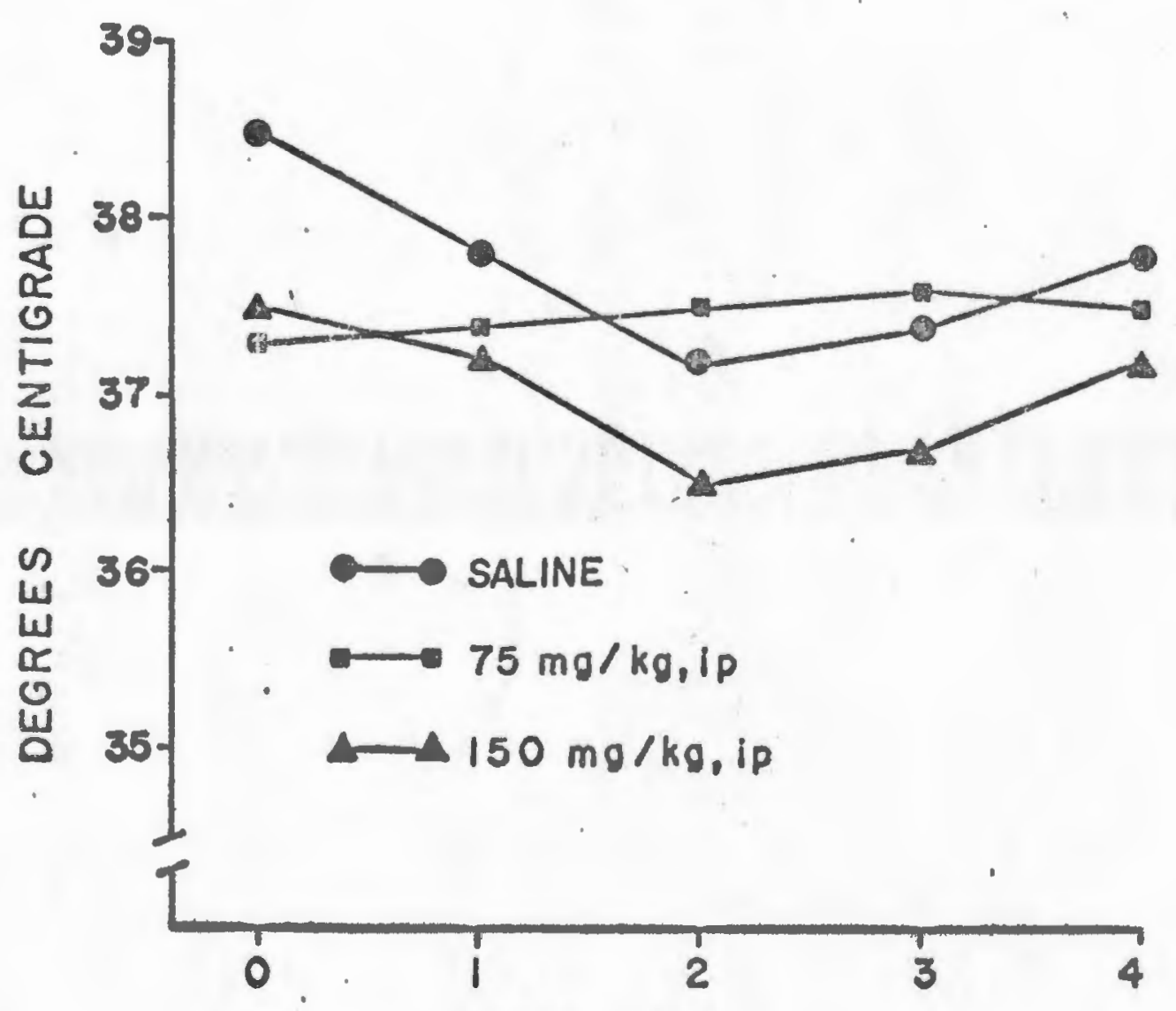

TIME, HR

Pigure 1. Effect of elOSA on rat body temperature. Animals were administered oithor saline or oltOSA ( 75 or $150 \mathrm{mg} / \mathrm{kg}$, ip) and rectal temperature was monitored over a period of 4 hours. Each point represents the mean temperature of 3 animala. 
Table 4. Effect of neutralized or buffered ec40SA on carrageenin-1nduced rat paw edema.

TREATMENT ${ }^{a}$

Saline

Neutral1zed ${ }^{c}$

(100 $\mathrm{mg} / \mathrm{kg}$, 1p)

Buffered ${ }^{d}$

(100 $\mathrm{mg} / \mathrm{kg}$, 1p)
MEAN EDEMA $\pm \mathrm{SE}, \mathrm{mm}^{3},(6)^{\mathrm{b}}$

$1174 \pm 99$

$898 \pm 181$

$678 \pm 176^{e}$
\% CONTROL

100

76

58

${ }^{a}$ Drugs were administered $I$ hour prior to carrageenin injection.

Number of animals.

${ }^{c}$ Neutralized to $\mathrm{pH} 7.4$ with $\mathrm{NaOH}$.

$\mathrm{d}_{\text {Burfered at } \mathrm{pH}} 7.4$ with $0.2 \mathrm{M} \mathrm{KH}_{2} \mathrm{PO}_{4}-\mathrm{Na}_{2} \mathrm{HPO}_{4}$.

$e_{P}<.05$ 
The enzyme activities reported are corrected for direct drug Inhibition, if any. Table 5 shows that acid phosphatase activity is insensitive as an indicator of lysosomal membrane condition, since the powerful stabllizing agent phenylbutazone inh1b1ted enzyme release by only $7 \%$. However, phenylbutazone $(0.309 \mathrm{mg} / \mathrm{ml})$ and the extract at a concentration of e1ther 3.087 or $0.309 \mathrm{mg} / \mathrm{ml}$ offered signif1cant $(P<.01)$ inhibition of release of $\beta$-glucuronidase $(30,36$, and 36 per cent of control respectively). Phloroglucinol and $0.031 \mathrm{mg} / \mathrm{ml}$ f40SA were ineffective. Table 6 shows that the extract retains its lysosomal membrane stabllizing ab1lity even when further chemically purlfled. The refined materlal offered statistically signiflcant $(P<.01)$ inhibition of release of B-glucuronidase ( $43 \%$ of control).

The extract was further tested for ant1-inflammatory activity by means of the Freund's adjuvant-induced rat paw edema model of arthritis. Table 7 summarizes the results of this study. The potent steroid triamcinolone inhibited edema formation by $77 \%(P<.05)$, in contrast to the extract, whlch provided negliglble protection against this type of inflammation.

Cap1llary fragility

The effect of the extract on capillary fragility as determined by lung hemoglobin content following sudden decompression was examined. Table 8 is a summary of this study. None of the drugs tested, wh1ch Included e40SA, 
Table 5. Effect of drugs on lysosomal membrane stab1l1ty in vitro.

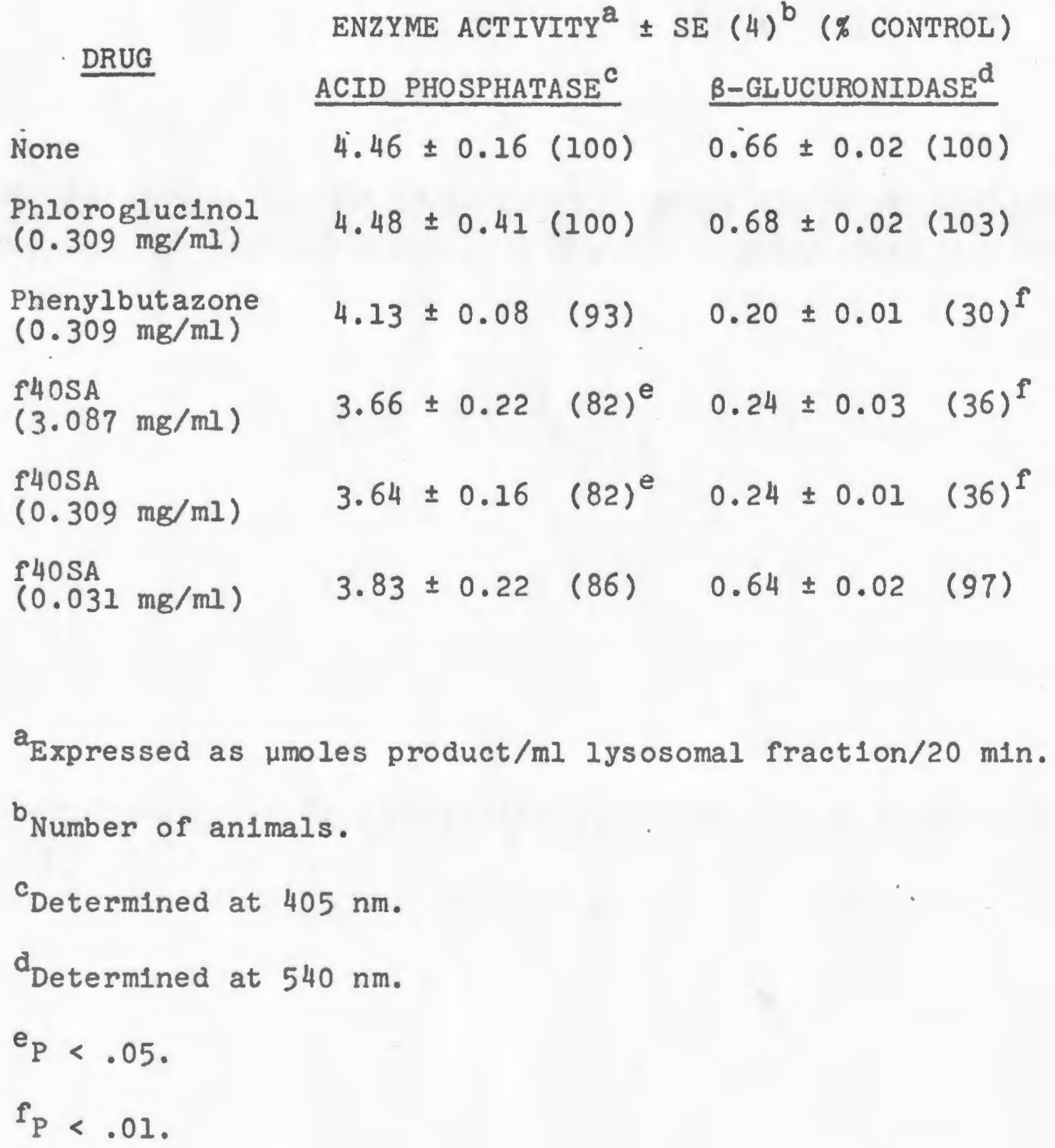


Table 6. Effect of P4OSA and refined 40SA on lysosomal membrane stablilty in vitro.

DRUG B-GLUCURONIDASE ACTIVITY ${ }^{a} \pm S E(4)^{b}$ ( $\%$ CONTROL)

None

$0.53 \pm 0.04(100)$

I4OSA

$(0.309 \mathrm{mg} / \mathrm{ml})$

$0.20 \pm 0.03(38)^{c}$

Refined $40 \mathrm{SA}$

$(0.309 \mathrm{mg} / \mathrm{ml})$

$0.23 \pm 0.02(43)^{c}$

axpressed as umoles phenolphthalein/ ml lysosomal

fraction/ $20 \mathrm{~min}$., determined at $540 \mathrm{~nm}$.

${ }^{b}$ Number of animals.

$c_{p}<.01$. 
Table 7. Antagonism of Freund's adjuvant-1nduced rat paw edema

TREATMENT

Saline

Triamcinolone

(2 $\mathrm{mg} / \mathrm{kg}, \mathrm{sc}$ )

P4OSA

(75 $\mathrm{mg} / \mathrm{kg}$, 1p)
MEAN EDEMA $\pm \mathrm{SE}, \mathrm{mm}^{3}(6)^{\mathrm{b}}$

$3920 \pm 983$

$911 \pm 153^{c}$

$3079 \pm 286$
CONTROL 100

23

79

arugs were administered daily for 17 days; adjuvant injected on second treatment day.

${ }^{\mathrm{b}}$ Number of animals.

$c_{P}<.05$

$\mathrm{d}_{\text {Adfusted to } \mathrm{pH}} 7.0$ with $\mathrm{NaOH}$. 
Table 8. Effect of drugs on the mouse lung hemmorrhage Induced by sudden decompression.

TREATMENT $^{2}$

TREATMENT

Saline

EUOSA

$(300 \mathrm{mg} / \mathrm{kg}, 1 \mathrm{p})$

Phloroglucinol

(300 $\mathrm{mg} / \mathrm{kg}$, 1p)

Phenylbiutazone

$(100 \mathrm{mg} / \mathrm{kg}, 1 \mathrm{p})$
MEAN mg HEMOGLOBIN ${ }^{b} / m g$ DRY LUNG $\pm \operatorname{SE}(4)^{c}$

\section{TABLE}

CHAMBER

$0.136 \pm 0.005$

$0.154 \pm 0.007$

$0.145 \pm 0.009$

$0.164 \pm 0.006$

$0.129 \pm 0.005$

$0.152 \pm 0.008$

$0.165 \pm 0.025$

$0.170 \pm 0.006$

${ }^{a}$ Drugs were administered 1.5 hours prior to decompression.

${ }^{\mathrm{b}}$ Determinedat $540 \mathrm{~nm}$.

c Number of animals. 
phloroglucinol, and phenylbutazone, reduced capillary fragility in this test system.

Curare, strychnine, and tetrodotoxin poisoning

The extract was tested for its abllity to protect against poisoning in mice induced by curare, strychnine, or tetrodotoxin. Table 9 shows that if both curare and the extract were administered intraperitoneally, there existed protection against curare lethality. As shown in Table 10, if the curare was administered subcutaneously and the extract intraperitoneally, no protection was exhibited by the extract.

Further experimentation was performed to investigate the mechanism of action of the apparent curare antagonism of the extract. Table 11 shows that the materlal had a negligible in vivo effect on rat brain cholinesterase activity, in contrast to an in vitro inhibition of $53 \%$ $(P<.01)$. The extract was also tested for 1ts in vivo effect on the curarlzed cat gastrocnemius muscle. Jugular Infusion of $180 \mathrm{mg}$ of elOSA over a period of nine minutes exhibited no effect on the curarized muscle, in contrast to the anticholinesterase agent physostigmine, which completely restored contractile force after infusion of 0.18 mg over a perlod of three minutes.

To determine whether the extract might protect against poisoning due to other agents, its effects on strychnine and tetrodotoxin lethality were examined. In both cases, 
Table 9. Protection against curare polsoning in mice by e40SA.

CURARE DOSE

$(\mathrm{mg} / \mathrm{kg}, 1 \mathrm{p})$

0.30

0.37

0.45

0.52

0.60
NUMBER OF SURVIVORS

SALINE e40SA $(300 \mathrm{mg} / \mathrm{kg}, 1 \mathrm{p})^{2}$

$5 / 5^{b}$

$5 / 5$

$3 / 5$

$2 / 5$

$1 / 5$

$0 / 5$

$5 / 5$

4/5

$5 / 5$

$5 / 5$

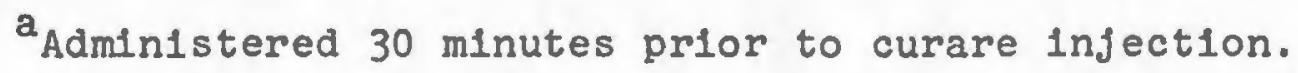

${ }^{b}$ Number of survivors/number infected. 
Table 10. Protection against curare poisoning in mice by ec40SA.

\begin{tabular}{l} 
CURARE DOSE \\
(mg/kg, sc) \\
\hline
\end{tabular}

0.28

0.36

0.144

0.52

0.60

\begin{tabular}{lc}
\multicolumn{2}{c}{ NUMBER OF SURVIVORS } \\
SALINE & ec40SA $\left(300 \mathrm{mg} / \mathrm{kg}_{2} \text { 1p) }\right)^{a}$ \\
\hline $4 / 5^{b}$ & $5 / 5$ \\
$3 / 5$ & $4 / 5$ \\
$2 / 5$ & $2 / 5$ \\
$1 / 5$ & $0 / 5$ \\
$0 / 5$ & $0 / 5$
\end{tabular}

${ }^{a d m i n i s t e r e d ~} 30$ minutes prior to curare injection.

${ }^{b}$ Number of survivors/number injected. 
Table 11. Effect of ec4OSA in vivo and in vitro on rat brain cholinesterase activity.

TREATMENT MEAN ENZYME ACTIVITY ${ }^{\mathrm{a}} \pm S E(3)^{\mathrm{b}} \cdot \underline{\text { CONTROL }}$

Saline

$2.96 \pm 0.20$

100

ec4OSA

$(300 \mathrm{mg} / \mathrm{kg}, 1 \mathrm{p})^{\mathrm{c}}$

$3.17 \pm 0.16$

107

ec4OSA

( $5 \mathrm{mg} / \mathrm{ml}$ )

$1.38 \pm 0.16^{\mathrm{d}}$

47

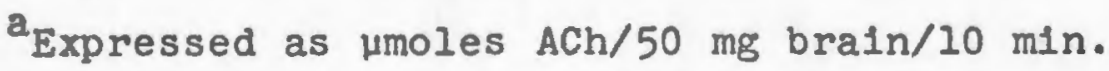

$\mathrm{b}_{\text {Number }}$ of animals.

${ }^{C}$ Administered one hour prior to sacrifice.

$d_{P}<.01$ 
the poison and the extract were administered by the intraperitoneal route. Tables 12 and 13 show that the extract does not protect against the lethality of elther strychnine or tetrodotoxin, respectively.

Ilver microsomal enzymes

The possible effect of the extract on the activity of the drug-metabolizing hepatic microsomal enzyme system was determined by measuring the effect of the extract on the metabolism of the pesticide EPN. Table 14 summarizes the results of the experiment. The classical inducing agent phenobarbital significantly increased microsomal enzyme activity by more than 4 -fold $(P<.01)$. The extract was ineffective in inducing this system after three days of treatment or in inhibiting the activity when given 60 minutes before sacrificing the animals.

Tryptophan pyrrolase

Table 15 summarizes the effects of various drugs on rat I1ver tryptophan pyrrolase activity. In vivo administration of hydrocortisone and 440 SA resulted in Increased enzyme activity ( $322 \%$ control, $P<.01)$ and Inhibition ( $67 \%$ control, $\mathrm{P}<.01$ ), respectively. In vivo administration of phloroglucinol had no effect on the enzyme activity, while the in vitro effect of phloroglucinol was that of inhibition ( $48 \%$ control, $\mathrm{P}<.01$ ). The presence of the Elsenian extract resulted in an in vitro Inhibition of $82 \%(P<.01)$. 
Table 12. Effect of ec40SA on strychnine poisoning in mice.

STRRYCHNINE ROUTE

(2 $\mathrm{mg} / \mathrm{kg})$

Ip

sc
NUMBER OF SURVIVORS

SALINE ec40SA $(300 \mathrm{mg} / \mathrm{kg}, 1 \mathrm{p})^{2}$

$0 / 4^{b}$

$0 / 4$

$0 / 4$

$0 / 4$

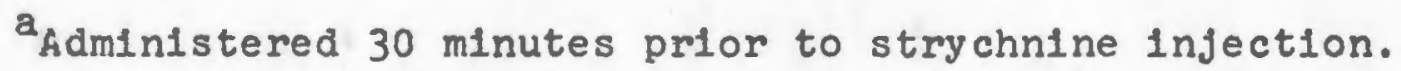

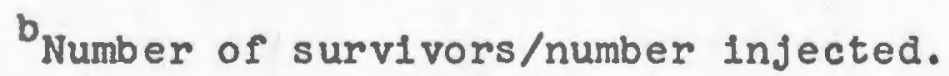


Table 13. Effect of f40SA on tetrodotoxin poisoning in mice.

TREATMENT $^{\mathrm{a}}$

Saline

S4OSA

(300 $\mathrm{mg} / \mathrm{kg}$, ip)
NUMBER OF SURVIVORS

$1 / 4^{b}$

$1 / 6$

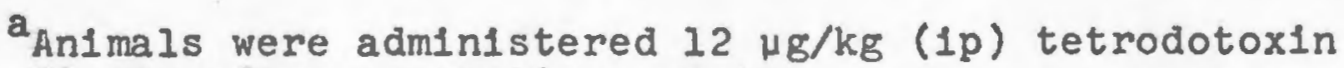
$30 \mathrm{~min}$ after protecting agent.

${ }^{b}$ Number of survivors/number injected. 
Table 14. Effect of drugs on $E^{2}{ }^{2}$ detoxification.

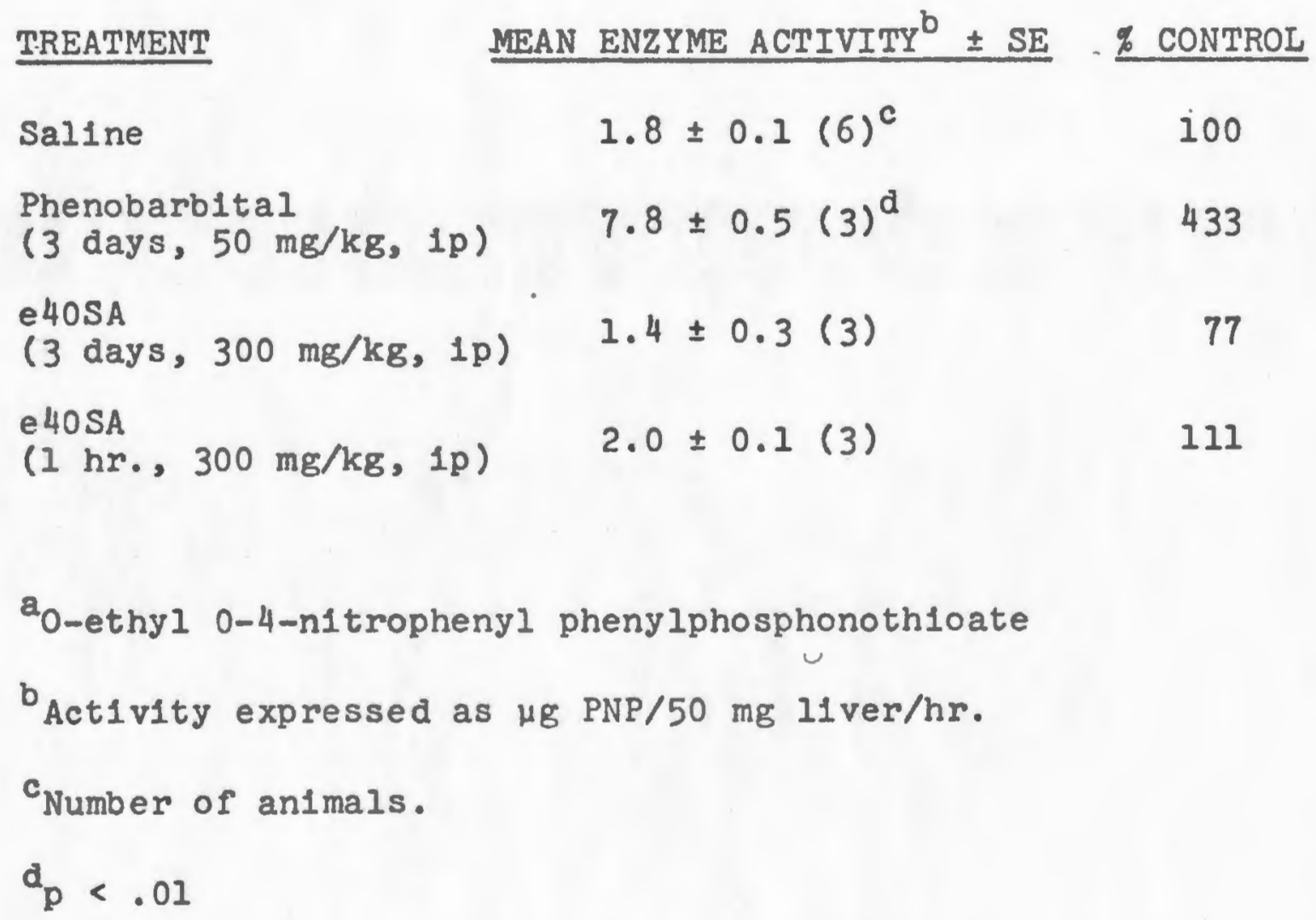


Table 15. Effect of drugs in vivo and in vitro on rat I1ver tryptophan pyrrolase activity.

TREATMENT

MEAN ENZYME ACTIVITY ${ }^{a} \pm S E(4)^{b} \approx$ CONTROL

Saline $e^{c}$

$20.6 \pm 0.5$

100

Hydrocortis one ${ }^{d}$

(35 $\mathrm{mg} / \mathrm{kg}, 1 \mathrm{p}$ )

$66.4 \pm 1.9^{e}$

322

Phloroglucinol ${ }^{c}$ (300 $\mathrm{mg} / \mathrm{kg}, 1 \mathrm{p}$ )

$19.8 \pm 0.3$

96

ᄃ40SA

$(300 \mathrm{mg} / \mathrm{kg}, 1 \mathrm{p})^{\mathrm{c}}$

$13.7 \pm 0.2^{e}$

67

Phloroglucinol

(486 $\mathrm{\mu g} / \mathrm{ml}$ )

$9.9 \pm 0.3^{e}$

48

ᄃ 40 SA

(486 $\mu \mathrm{g} / \mathrm{ml}$

$3.7 \pm 0.2^{e}$

18

$a_{\text {Expressed as }}$ moles kynurenine/g liver/hr.

${ }^{b}$ Number of animals.

${ }^{c}$ Administered 1.5 hours prior to sacrifice.

dAdministered 4 hours prior to sacrifice.

$e_{P}<.01$ 


\section{Rat uterus}

The extract was tested for possible estrogenic activity by examining its ability to alter the uterine to body welght ratio in 1mmature female rats. Table 16 shows the results of the study. Estradiol-17- $\beta$ increased the ratio more than 2 -fold $(P<.01)$, while the extract had no effect on the ratio. 
Table 16. Effect of drugs on rat uterine weight.

TREATMENT $^{\mathrm{a}}$ Uterine Wt. $\times 10^{3} \pm$ S.E. $(5)^{\text {b }}$ \% CONTROL

Saline (1p)

$0.69 \pm 0.06$

100

Estradiol

$(0.5 \mu \mathrm{g} / \mathrm{rat}, \mathrm{sc})$

$1.64 \pm 0.06^{c}$

238

ec40SA

(300 mg/kg, 1p)

$0.61 \pm 0.04$

88

a Drugs were administered dally for 3 days.

${ }^{b}$ Number of animals.

${ }^{c} \mathrm{P}<.01$ 


\section{$\mathrm{V}$ DISCUSSION}

\section{Inflammation}

The extract was initially evaluated for pharmacological activity utilizing the albumin heat denaturation screening test for ant1-1nflammatory drugs. A large number of ant1inflammatory drugs have been shown to inhibit the heat denaturation of albumin solutions (Grant et al., 1970). Heat denaturation is able to produce albumin aggregates which are immunologlcally distinct from the parent protein (Maurer, 1959). Such aggregates are known to occur spontaneously (Foster et al., 1965); these spontaneous aggregates behave as antigens in the et1ology of at least one Immuno-inflammatory disease, serum sickness nephritis (L1 renman et al., 1967).

The extract inhibited albumin denaturation by $96 \%$, as shown in Table 1, in contrast to the denaturation enhancement afforded by the model compound, phloroglucinol (Table 2). While the mechanism of such a stabilization is presentiy unknown, it is possible that hydrogen bonding occurs between the extract and the protein, thus increasing the stability of the molecular structure.

The in vitro anti-inflammatory screen was followed by in vivo anti-inflammatory determinations utilizing the carrageenin-induced rat paw edema model of inflammation, 
which is least influenced by non-specific factors (Garattini et al., 1965). The mechanism by which carrageenin, a high molecular welght polysaccharide, Induces paw edema is as controversial as the mechanisms of action of the agents which inhibit this edema formation. The following have been invoked as mediators of carrageenin-induced edema: kinins and 5-hydroxytryptamine (5-HT) (Crunkhorn and Meacock, 1971), histamine (DiRosa et al., 1971), and activation of the complement system (D1Rosa, 1972). It is possible that the apparent complement system activation reflects a mild antigen-antibody response to carrageenin, since high molecular weight polysaccharldes as well as protelns are capable of eliciting such a response (Porter, 1967). Thus, 5-HT and histamine release may be secondary to complement activation.

Administration of the extract one hour prior to carrageenin infection inhibited the formation of edema by $88 \%$. Accordingly, varlous experiments were undertaken to determine the mechanism of action of this protection. Since stimulation of the adrenal cortex, elther directly or indirectly via the hypothalamus or p1tu1tary, can be related to ant1inflammatory activity, the action of the extract was compared with that of a large dose of cortisone $(50 \mathrm{mg} / \mathrm{kg}, 1 \mathrm{p})$, which Inhibited edema production by $46 \%$. Since cortisone afforded only one-half the inhibition offered by the extract, it is unlikely that the extract could stimulate the production or release of sufficient corticosterold to reduce inflammation by the extent exh1b1ted. 
The thermogenic activity of new anti-inflammatory compounds must be determined since the peripheral vasodilation which would accompany a rise in body temperature might elther promote edema, due to increased capillary permeability, or reduce edema, by more rapid removal of phlogistin. The extract was tested for 1ts effect on body temperature, and it can be concluded from Figure 1 that the extract had a negligible effect on body temperature over a period of four hours. Thus the anti-inflammatory activity of the extract is not based on thermogenic effects.

Garattinl et al., (1965) have shown that various compounds, when injected by the intraperitoneal route, can Inhibit edema formation in various models of inflammation due to their properties as 1rritants. A partial basis for this phenomenon is decreased avallability of clrculating fluid due to the draining of water into the peritoneal cavity. Accordingly, an experiment was undertaken to determine if the extract was an irritant by virtue of 1 ts acldity. Employing the carrageenin model, extract was tested which was maintained at $\mathrm{pH} 7.4$ elther by phosphate buffering or sodium hydroxide neutralization. The results of the experiment are shown in Table 4, and 1t is evident that although the anti-inflammatory potency of the extract has been decreased by neutralization, the buffered material retains statistically significant anti-inflammatory activity which is one-half that of non-adjusted, acldic extract solution. Thus the mechanism of action of the extract can 
be partially, but not fully, explained on the basis of 1 ts Irritancy.

Lab1lization of the lysosomal membrane is known to occur at sites of infury and has also been 1mplicated as a major factor in the development of inflammation, since lysosomal enzymes possess the capac1ty to degrade completely the components of the connective tissue, such as collagen, proteln-mucopolysaccharide complexes, glycoprote1n, and elast1n (Houck and Forscher, 1968; Ignarro, 1971). Many ant1-inflammatory agents have been shown to stab1lize the Iysosomal membrane through their inhibition of the release of the marker enzymes $\beta$-glucuronidase and actd phosphatase from lysosomal preparations. The extract was examined in this manner. It can be concluded from the data in Table 5 that the extract is as effective as phenylbutazone as a Iysosomal membrane stab1l1zing agent.

Since the crude extract might contain an Impurity which would account for the lysosomal membrane stablilization, a refined sample of the extract was also tested for 1ts ability to Inhibit the release of B-glucuronidase from lysosomal preparations. The results, summarized in Table 6, show that the refined material is as effective as the crude in its abllity to stab1lize the lysosomal membrane.

The extract was further tested for anti-inflammatory activity by means of the adjuvant arthritis model, which is a delayed hypersensitivity reaction. Table 7 shows the results of the study, and it can be concluded that the 
extract exerted no ant1-1nflammatory effect against this type of inflammation. The mechanism by which effective agents, such as triamcinolone, combat this model of arthritis is obscure, but may be in part due to lysosomal stab1lization (Pollock and Brown, 1971).

An hypothesis may be formulated to account for the contrasting effects of the extract on the two in v1vo models of inflammation. "Primary" membrane stab1lization (stabil1zation of membranes of whole cells, e.g., basophils, platelets, or mast cells) and "secondary" membrane stab1l1zation (stab1lization of the membranes of cell organelles, e.g. lysosomes) apparently are involved in the etlology of both carrageenin and Freund's edema. The extract has been shown to stab1lize at least one type of membrane, that of the lysosome. However, Freund's edema may be more difficult to suppress than carrageenin edema because of overwhelming participation of the 1mmunity mechanism in the case of the former.

The extract, by v1rtue of 1ts polysaccharide content, might also act as a counter-1rritant.

\section{Cap1liary frag1l1ty}

The extract was examined for 1ts ab1l1ty to decrease caplllary fragility. It should be noted that the method of Majovsk1 (1944) was employed except in the comparis on of different treatments, for which a quantitative spectrophotometric assay for hemoglobin was used in place of the arb1trary qualitative assay originally described. 
The method employed is non-specific in that the underlying mechanism of a stabliling agent cannot be different1ated from the known possibilities, which include effects on the 1) endothellal cell membrane, 2) endothellal cell Junction, and 3) sources of possible chemical intermediates (such as basophlls, and platelets, and plasma kinins).

None of the drugs tested enhanced caplllary stab1lity (Table 8) in contrast to the effect of phloroglucinol reported by Okanishi and Shimaoka (1952). Close examination of the results shows that the method is not sufficiently sensitive to quantitate the possible stabilizing effects of drugs, Inasmuch as the chamber control animals exhibited only a 13\% increase in lung hemoglobin compared to the nonchamber animals. This increase is not statistically significant. Curare, strychnine, and tetrodotoxin poisoning

The extract was tested for its effectiveness as an antagonist against curare, strychnine, and tetrodotoxin, because of the report of Mogey and Young (1949) that phloroglucinol acted as a mild curare antagonist in vitro. These three agents act on the nervous system dissimilarly: 1) curare, the classical neuromuscular blocker, competitively blocks postjunctional acetylcholine receptor sites, 2) strychnine, a CNS stimulant, acts by blocking post-synaptic inhibition, and 3 ) tetrodotoxin selectively blocks axonal conduction.

Since the extract was ineffective in preventing curare 
poisoning when adminlstered via a different route than that of the curare, in contrast to the protection exhibited when the routes of administration were identical (Tables 9-10), a true pharmacological antagonism would seem an unlikely mechanism of action of the extract. This was supported by demonstrating that 1) the extract was an ineffective in vivo cholinesterase inhibitor (Table 11) and 2) the extract exerted no antagonism to the action of curare on the in vi vo cat gastrocnemius muscle-sciatic nerve preparation. An alternative mechanism of action might be based on the occurrence of a chemlcal interaction of the negatively charged extract molecule with the positively charged quaternary nitrogen of the curare molecule. Further experimentation in this context falled to support such a mechanlsm: while no protection was offered against the lethallty of strychnine, which contains an uncharged tertiary nitrogen ( Table 12), neither was there protection against polsoning by tetrodotoxin which contains a positively charged guanidinium group (Table 13). An untested hypothesis for the curare protection might be an inhibition of absorption of the curare from the peritoneal cavity.

Liver microsomal enzymes

In order to more fully characterize the action of a new drug, its interaction with other drugs must be examined. One potential site of drug interaction is the liver microsomal electron transport system, an enzyme 
system which is responsible for the blotransformation of a wide variety of drugs and other chemical agents. Most important relative to drug interactions are the stimulation (Induction) and inhibition of the system.

The extract was tested for possible microsomal induction or inhibition (Table 14) by measuring the effect on the metabolism of the insectide EPN. The extract was observed to have no effect on microsomal enzymes after administration dally for three days or one hour following a single dose. Tryotophan pyrrolase

Tryptophan pyrrolase, located in the soluble fraction of the liver cell, catalyzes the cleavage of the indole ring from the nutritionally essential amino acid tryptophan. The resultant product, formyl kynurenine, is readily hydrolyzed to kynurenine. Tryptophan pyrrolase is important not only for tryptophan degradation but also for the conversion of tryptophan to niacin. The enzyme is inducible; known inducIng agents include adrenal corticosterolds and tryptophan itself.

Investigation of the effect of the extract on the activity of tryptophan pyrrolase would provide a more complete characterization of the effects of the extract on liver metabolism, in conjunction with the effects exerted on the microsomal enzyme system, especially since Frieden et al. (1961) reported that phloroglucinol inhibited tryptophan pyrrolase in vitro. Such an investigation was carried out and the results, shown in Table 15, indicate that the 
extract, both in vivo and 1n vitro, caused enzyme inhibition. Such Inhibition could result in nicotinic ac1d deficlency or in increased synthesis of serotonin, which might result in st1mulation of cerebral act1vity.

Rat uterus

A varlety of naturally occurring phenolic materials have been shown to exh1b1t estrogenic activity (B1ggers and Curnow, 1954); the widespread metabolic consequences of such activity seemed sufficlent justification for determinIng whether the extract acted in a similar manner. The uterus, target organ for estrogen, is most frequently employed to bloassay for estrogenic activity. The response of this organ to estrogenic stimulation is biphasic in nature: 1n1t1ally, hyperemia and 1mb1b1tion of water occur, followed later by hypertrophy and hyperplasia; thus an Increase in the uterine to body welght ratio can be demonstrated.

The extract was found to cause ne1ther estrogenic st1mulation nor retrogression of th1s organ (Table 16). 


\section{SUMMARY AND CONCLUSIONS}

1. An extract from Eisenia bicyclis containing principally a polyphenolic polymer inhibited the heat denaturation of a $0.15 \%$ bovine serum albumin by $96 \%$ when added to the incubation medium at a concentration of $0.32 \mathrm{mg} / \mathrm{ml}$. This was suggestive of possible anti-inflammatory activity.

2. As determined by paw volume changes, administration of the extract at a dose of $75 \mathrm{mg} / \mathrm{kg}$ one hour prior to carrageenin infection inhibited edema production by $88 \%$.

3. The ability of the extract to suppress carrageenin edema was apparently not due to pituitary-adrenal stimulation, since a large dose of cortisone $(50 \mathrm{mg} / \mathrm{kg})$ provided only one-half the protection afforded by the extract. Nor was the anti-inflammatory effect due to changes in body temperature, which remained unchanged over a period of four hours after administration of a dose of elther 75 or $150 \mathrm{mg} / \mathrm{kg}$.

4. The ant1-inflammatory effect of the extract was partially due to 1ts irritant properties, since buffering a dose of $100 \mathrm{mg} / \mathrm{kg}$ provided only one-half the protection afforded by a non-buffered dose. The extract may also act against inflammation by stabilizing the lysosomal 
membrane, since 1n vitro $309 \mu \mathrm{g}$ of the extract per milliliter of incubation medium inhibited by $64 \%$ the release of the marker enzyme $\beta-g l u c u r o n i d a s e$ from rat liver lysosomes.

5. The extract administered at a dose of $75 \mathrm{mg} / \mathrm{kg}$ da1ly for 17 days offered no protection against rat paw edema Induced by Freund's complete adjuvant.

6. No decrease in capillary fragility of the mouse lung, as determined by hemoglobin content following sudden decompression, was observed 1.5 hours after pretreatment with the extract at a dose of $300 \mathrm{mg} / \mathrm{kg}$.

7. The material administered to $\mathrm{mlce}$ at a dose of $300 \mathrm{mg} / \mathrm{kg}$ 30 minutes prior to administration of lethal doses of curare exhiblted protection against curare polsoning only if the routes of administration were 1dentical.

8. The mechanism of action of the apparent curare antagonIsm of the extract appeared to be chemical rather than pharmacological, since the material had no effect on e1ther the curarized cat gastrocnemius muscle in v1vo or the activity of rat brain cholinesterase in vivo. An exact chemical mechanism cannot be formulated because the material was ineffective in preventing polsoning by elther another positively charged toxin, tetrodotoxin, or an uncharged poison, strychnine.

9. The extract was observed to have no effect on 11 ver microsomal enzyme activity after administration of 300 $\mathrm{mg} / \mathrm{kg}$ dally for three days or one hour following a 
single dose of $300 \mathrm{mg} / \mathrm{kg}$.

10. The administration of the extract at a dose of 300 $\mathrm{mg} / \mathrm{kg} 1.5$ hours prior to sacrifice resulted in $33 \%$ Inhibition of the activity of tryptophan pyrrolase. The presence of the extract at a concentration of $486 \mu \mathrm{g} / \mathrm{ml}$ resulted in an in vitro inhibition of $82 \%$.

11. The extract, administered at a dose of $300 \mathrm{mg} / \mathrm{kg}$ dally for three days, did not alter the uterine to body weight ratio in immature female rats. 


\section{REFERENCES}

Bickoff, E. M., et al.: Isolation of a new estrogen from ladino clover. J. Agric. Fd. Chem. 6: 536-539, 1958.

Biggers, J. D. and D. H. Curnow: Oestrogenic activity of subterranean clover. Blochem. J. 58: 278-282, 1954.

Conney, A. H.: Pharmacological implications of microsomal enzyme induction. Pharmacol. Rev. 19: 317-366, 1967.

Crunkhorn, P. and S. C. R. Meacock: Mediators of the inflammation incuced in the rat paw by carrageenin. Brit. J. Pharmacol. 42: $392-402,1971$.

Der Marderosian, A.: Marine pharmaceuticals. J. Pharm. Sc1. 58: 1-33, 1969.

DiRosa, M.: Biological properties of carrageenan. J. Pharm. Pharmacol. 24: 89-102, 1972.

DiRosa, M., et al.: Studies of the mediators of the acute Inflammatory response induced in rats in different sites by Carrageenan and Turpentine. J. Path. 104: 15-29, 1971.

DuBo1s, K. P. and G. H. Mangun: Effect of hexaethyl tetraphosphate on cholinesterase in vitro and in vivo. Proc. Soc. Expt1. B101. Med. 64: $137-139,1947$.

Foster, J. F., et al.: Microheterogene1ty of plasma albumins. J. BIol. Chem. 240: 2495-2502, 1965.

Frieden, E., et al.: Inhibition of tryptophan pyrrolase by serotonin, epinephrine, and tryptophan analogs. Arch. Blochem. Blophys. 92: 176-182, 1961.

Garattini, S., et al.: Sensitivity of local edemas to systemic pharmacological effects. In Non-steroidal antiInflammatory drugs, Excerpta Medica Foundation, Amsterdam, $155-161,1965$.

Grant, N. H., et al.: Stabilization of serum albumin by anti-inflammatory drugs. Biochem. Pharmacol. 19: 715$722,1970$. 
Houck, J. C. and B. K. Forscher, editors, Chemical Blology of Inflammation. Pergammon, Oxford, 1968.

Ignarro, L. J.: Effects of ant1-inflammatory drugs on the stability of rat liver lysosomes in vitro. Blochem. Pharmacol. 20: 2847-2860, 1971.

Knox, $\&$. E. and A. H. Mehler: The conversion of tryptophan to Kynurenine in 11ver. J. B1ol. Chem. 187: 419-430, 1950.

IIrenman, D. S., et al.: Role of aggregated bovine serum albumin in pathogenesis of serum sickness nephritis in rabbits. Proc. Soc. Exp. B1ol. Med. 125: 231-234, 1967.

Majovsk1, G. J., et al.: Vascular frag1lity and permeability as Lnfluenced by various agents. J. Pharm. Exptl. Ther. 80: $1-7,1944$.

Maurer, $p$. H.: Modifled bovine serum albumin. VI. Immunochemical and physicochemical properties of BSA denatured by varlous agents. Archs. Blochem. Blophys. 79: 13-26, 1959.

Mogey, G. A. and P. A. Young: The antagonism of curarizing activity by phenol1c substances. Brit. J. Pharmacol. 4: $359-365,1949$.

Neal, R. A. and K. P. DuBo1s: Studies on the mechanlsm of detoxification of cholinergic phosphorothioates. J. Pharmacol. Exptl. Ther. 148: 185-192, 1965.

Okanish1, T. and A. Shimaoka: Pharmacological studies of flavone derivatives $I$, capillary stabilizing effect. Ann. Repts. Shionogi Res. Labs. No 2: 162-166, 1952.

Pearson, C. M.: Development of arthrit1s, periarthritis, and periostitis in rats given adjuvants. Proc. Soc. Expt1. Biol. Med. 91: 95-101, 1956.

Pollock, S. H. and J. H. Brown: Studies on the acute inflammatory response. III. Glucocorticolds and Vitamin E in vivo attenuate thermal labilization of 1solated hepatic Iysosomes. J. Pharmacol. Expt 1. Ther. 178: 609-615, 1971.

Porter, R. R.: The structure of antibodies. Sc1. Am. 217: $81-90,1967$.

Van Arman, C., et al.: Some detalls of the inflammations caused by yeast and carrageenin. J. Pharmacol. Exp. Ther. 150: $328-334,1965$. 
Winter, C. A., et al.: Carrageenin-induced edema in hind paw of the rat as an assay for anti-inflammatory drugs. Proc. Soc. Expt1. B1ol. Med. 111: 544-547, 1962.

Zelensk1, S. G.: Ph.D. Thesis, University of Rhode Island, 1973. 